\title{
Effects of Decomposing Leaf Litter of Eucalyptus grandis on the Growth and Photosynthetic Characteristics of Lolium perenne
}

\author{
Yiqiao Li ${ }^{1}$, Tingxing $\mathrm{Hu}^{1}$, Xiaoyu Duan ${ }^{2}$, Fanming Zeng ${ }^{1}$, Hong $\mathrm{Chen}^{1} \&$ Xiuhua $\mathrm{Wu}^{1}$ \\ ${ }^{1}$ Key Laboratory of Forestry Ecological Engineering of Sichuan Province, College of Forestry, Sichuan \\ Agricultural University, China \\ ${ }^{2}$ College of Landscape Architecture, Sichuan Agricultural University, Sichuan, China \\ Correspondence: Tingxing Hu, Key Laboratory of Forestry Ecological Engineering of Sichuan Province, College \\ of Forestry, Sichuan Agricultural University, China. Tel: 86-835-288-2335. E-mail: hutx001@yahoo.com.cn
}

Received: December 27, 2012 Accepted: January 14, 2013 Online Published: February 5, 2013

doi:10.5539/jas.v5n3p123 URL: http://dx.doi.org/10.5539/jas.v5n3p123

\begin{abstract}
The essence of grass growth is a complex system that is driven by light energy. The accumulation of $90 \%$ of the dry matter comes from the production of photosynthesis. In this study, we investigated the effect of decomposing leaf litter of Eucalyptus grandis on the growth and photosynthetic characteristics of Lolium perenne by pot experiment. Four treatments with different amounts of leaf litter were designed, including A1 (30 g/pot), A2 (60 $\mathrm{g} / \mathrm{pot}), \mathrm{A} 3(90 \mathrm{~g} / \mathrm{pot})$ and control $(0 \mathrm{~g} /$ pot; $\mathrm{CK})$, and the blank experiment groups with distilled fallen leaves were set as the above. The growth indices (including shoot biomass, root biomass and leaf area) were measured, and the photosynthetic characteristics were tested during 9:00-11:00 am on a sunny day. The test results showed that increasing amounts of $E$ grandis leaf litter significantly inhibited the accumulation of shoot and root biomass, growth of leaf area, synthesis of photosynthetic pigments (chlorophyll $\mathrm{a}$, chlorophyll $\mathrm{b}$ and cartenoids), photosynthetic rate and gas exchange parameters $(G s, C i$ and $T r)$ of $L$. perenne seedlings $(P<0.05)$. The parameters of photosynthetic rate in response to $\mathrm{CO}_{2}$ concentration and light intensity showed a remarkable downward trend except for the $\mathrm{CO}_{2}$ compensation point and were significantly difference from $\mathrm{CK}$, namely, $\mathrm{CK}>$ A1 $>$ A2 $>$ A3 $(P<0.05)$. The blank experimental showed that soil chemical and physical properties have not been changed by leaf litter decomposition. This demonstrated that the allelochemicals from E. grandis leaf litter decomposition can negatively affect the photosynthetic capacity and decrease the accumulation of biomass, and eventually inhibit the growth of $L$. perenne.
\end{abstract}

Keywords: allelopathy, Eucalyptus grandis, leaf litter, Lolium perenne, growth, photosynthesis

\section{Introduction}

Eucalyptus grandis was first discovered in Australia and the adjacent islands. It is a tall straight-trunked tree that grows extremely fast in warm and humid climates. Because of its great environmental adaptability, excellent form and rapid growth, it is the most widely planted industrial eucalypt (Jairus et al., 2011). Since this species was introduced to China in the early 1990s, extensive plantations have teemed in the southern part of China, especially in Sichuan province (Zhang et al., 2008). Although Eucalyptus (E. grandis) plantation brought great economic benefits, the negative effects on ecological diversity and ecosystems degradation has also resulted and drawn our great attention (Campoe et al., 2013). According to reports, the leaf litter of $E$. grandis contains at least eight kinds of chemical substance, such as alkanes, aromatic hydrocarbons, esters etc (Goya et al., 2008). Among these compounds, the phenols, terpene and esters are the major allelochemicals, which can influence the growth of undergrowth (Yu et al., 2009). Therefore, ecological diversity would be affected by E. Grandis, which would degrade the ecosystem.

Recently, with the interconnection between forestry and agrostology (branch of botany that deals with the study of grasses), and the requirement that there be comprehensive treatment of the ecological environment, people are paying more and more attention to forest-grass compound management. This can make full use of resources in the forest, increase vegetation coverage of the understory and balance the ecological, economic and social benefits, and is an important management mode in plantation (Wang et al., 2003). 
Perennial Ryegrass (Lolium perenne), which belongs to the Lolium genus in the Gramineae family, is an annual or perennial herb with better traits of tenderness, nutrition and taste. It is also an important pasture and green manure grass (Lee et al., 2010). The mixed planting between L. perenne and E. grandis probably can mitigate the ecological problems in E. grandis monoculture, and has an important effect on the utilization of forestland. Generally, leaf litter of $E$. grandis is plowed into the soil while conducting the forest-grass management mode, so the grass may be affected by the allelochemicals from leaf litter decomposition.

Currently, there are few studies on the allelopathic effect of E. grandis on the undergrowth plants using the method of simulation experiment in the greenhouse. Consequently, it is important to discuss the mechanism of allelopathy of $E$. grandis on $L$. perenne. The objective of this experiment was to determine the effect of decomposing $E$. grandis leaf litter on the growth and photosynthetic characteristics of $L$. perenne in a natural state, and provide research and reasonable suggestions on allelopathy, provide a management strategy for $E$. grandis plantation and its compound system with grass as well.

\section{Method}

\subsection{Site for Experiment}

The experiment was performed in a big plastic shed at the Forestry Station of Sichuan Agricultural University $\left(101^{\circ}\right.$ $56^{\prime} 2^{\prime \prime}-103^{\circ} 22^{\prime} 35^{\prime \prime} \mathrm{E}, 28^{\circ} 51^{\prime} 18^{\prime \prime}-30^{\circ} 56^{\prime} 30^{\prime \prime} \mathrm{N}, 600-750 \mathrm{~m}$ a.s.l.), Ya'an, Sichuan province, where is a typical $E$. grandis plantation region in the southwest China. Mean annual precipitation, annual temperature and relative air humidity in this area is $1800 \mathrm{~mm}, 16.2^{\circ} \mathrm{C}$, and $79 \%$, respectively. The annual cumulative temperature $\left(\geq 10^{\circ} \mathrm{C}\right)$ is $5231^{\circ} \mathrm{C}$, annual sunshine is $1039.6 \mathrm{~h}$, and frost-free period is $298 \mathrm{~d}$.

\subsection{Research Design}

The soil texture is typical sandy loam with the $\mathrm{pH}$ of 7.85 and the organic matter content is $24.38 \mathrm{~g} / \mathrm{kg}$. The soil fertility status is as follows: total N $0.66 \mathrm{~g} / \mathrm{kg}$; total P $0.67 \mathrm{~g} / \mathrm{kg}$; total $\mathrm{K} 5.57 \mathrm{~g} / \mathrm{kg}$; available P $14.73 \mathrm{mg} / \mathrm{kg}$ and available K $15.15 \mathrm{mg} / \mathrm{kg}$. The test soil was sterilized by carbendazim after sieving with $2 \mathrm{~mm}$ mesh. Polyethylene pots with capacity of $12 \mathrm{~kg}$ soil ( $29 \mathrm{~cm}$ in diameter of opening, $17 \mathrm{~cm}$ in diameter of bottom and $22 \mathrm{~cm}$ in height) were employed for planting. Fresh fallen leaves were randomly collected from the 10 year old E. grandis plantation in the experiment site, and cut into small pieces of about $1 \mathrm{~cm}^{2}$ after natural withering, then weighed and very good mixed with disinfected soil. The healthy seeds of $L$. perenne were disinfected with $0.05 \% \mathrm{KMnO}_{4}$ for 20 min, and soaked in the warm water for $2 \mathrm{~h}$ after washing.

Three treatments were applied according to the annual amount of leaf fall in pure matured E. grandis plantation ( $\left.9000 \mathrm{~kg} / \mathrm{hm}^{-2}\right)$, including A1 (30 g/pot), A2 (60 g/pot), A3 (90 g/pot) and a control group was also set ( $\left.0 \mathrm{~g} / \mathrm{pot}\right) .30$ seeds were planted in each pot with 10 replicates in every treatment on $10^{\text {th }}$ March 2012 . The soil moisture was kept at $80 \%$ of the field capacity. The growth indices were measured on $15^{\text {th }}$ May 2012.

In order to observe the effect of addition of leaf litter on the soil permeability and aeration, the blank experiment without allelochemicals was set. The fallen leaves, the allelochemicals of which have been removed by distillation, were mixed with soils, and then 4 treatments $(0,30,60,90 \mathrm{~g} / \mathrm{pot})$ were applied as above. The growth traits (leaf area and dry matter mass) and net photosynthetic rate were measured on $15^{\text {th }}$ May 2012.

\subsection{Indices Measuring}

The photosynthetic characteristics of $L$. perenne leaf were monitored using portable photosynthesis analyzer (Li 6400 , Li-Cor Inc., USA). The concentration of carbon dioxide was controlled at $400 \mu \mathrm{mol} \mathrm{CO}_{2} / \mathrm{mol}$, temperature was $25^{\circ} \mathrm{C}$ and light intensity was $1500 \mu \mathrm{mol} \mathrm{m}^{-2} \mathrm{~s}^{-1}$. Then the net photosynthetic rate $\left(P_{n}\right)$, transpiration rate $\left(T_{r}\right)$, stomatal conductance $\left(G_{s}\right)$ and intercellular $\mathrm{CO}_{2}$ concentration were measured during 9:00-11:00 am on 17 $7^{\text {th }}$ May 2012 (a sunny day), with six replications in each test.

Pigment content was measured by the method of equally mixing ethanol and acetone using the leaves which have been used for measuring of photosynthetic parameters, including chlorophyll a (Chl a), chlorophyll b (Chl b) and carotenoids (Car) (Li et al., 2000). The ripe leaves collected from same part of different treatments were used for measuring the leave area using a portable laser leaf area meter (Li-3100, Li-Cor, USA). The total bud lengths and roots of 10 seedlings for each treatment were measured and repeated for triplication. The shoots and roots from seedlings were dried in an oven at $105^{\circ} \mathrm{C}$ for $30 \mathrm{~min}$ to deactivate enzymes and then dried to constant mass at $80^{\circ} \mathrm{C}$ for determination of dry mass (overground part and underground part), and calculate the root-shoot ratio (shoot biomass/root biomass). 


\subsection{Statistical Analysis}

Statistics analyses were performed using SPSS 18.0 software. One-way ANOVA was used to compare the effect of treatments. Least Significant Difference (LSD) method was used for multiple comparison tests, the p-value for significance was set at $P<0.05$. The program of correlation analysis is used to identify and measure the associations among different traits.

The Photosyn Assistant 1.1.2 was employed to fit the light response curve, and light- $\mathrm{CO}_{2}$ response curve was fitted by rectangular hyperbolic model.

Response index (RI) of allelopathy was calculated using the formula by Williamson and Richardson (1988):

$$
R I=1-\mathrm{C} / \mathrm{T}(\mathrm{T} \geq \mathrm{C}) \text { and } R I=\mathrm{T} / \mathrm{C}-1(\mathrm{~T}<\mathrm{C})
$$

Where, $\mathrm{C}$ is the control response and $\mathrm{T}$ is the treatment response. The range of $\mathrm{RI}$ is from -1 to +1 , and with positive values indicating stimulation by the treatments, whereas the negative values indicating inhibition by them, relative to the controls.

\section{Results}

\subsection{Effect of Decomposing Leaf Litter of E. grandis on the Biomass and Leaf Area of L. perenne Seedlings}

The biomass (shoot and root) and the leaf area of $L$. perenne declined significantly with the increase of leaf litter of E. grandis in soil of the three different treatments, shown as CK $>$ A1 $>$ A2 $>$ A3 $(P<0.05)$, namely, the CK group without litter had the best production in biomass and there was a drop as the amount of litter increased. Whereas the response index of allelopathy went up along with the leaf litter increasing in shoot biomass, root biomass and leaf area, and the indices in $\mathrm{A} 3$ treatment reached $-0.77,-0.87$ and -0.72 , respectively (Table 1 ).

Table 1. Effects of leaf litter decomposition of E. grandis on the biomass and leaf area of L. perenne seedlings

\begin{tabular}{lllllllc}
\hline Treatment & $\begin{array}{l}\text { Shoot biomass } \\
(\mathrm{g} / 10 \text { plants })\end{array}$ & $R I$ & $\begin{array}{l}\text { Root biomass } \\
(\mathrm{g} / 10 \text { plants })\end{array}$ & $R I$ & $\begin{array}{l}\text { Leaf area } \\
\left(\mathrm{cm}^{2} / 10 \text { plants }\right)\end{array}$ & $R I$ & Root/Shoot \\
\hline CK & $5.73 \pm 0.12^{\mathrm{a}}$ & $\backslash$ & $1.97 \pm 0.14^{\mathrm{a}}$ & $\backslash$ & $5.12 \pm 0.47^{\mathrm{a}}$ & $\backslash$ & $0.34 \pm 0.03^{\mathrm{a}}$ \\
A1 & $4.89 \pm 0.11^{\mathrm{b}}$ & -0.48 & $1.42 \pm 0.09^{\mathrm{b}}$ & -0.58 & $3.98 \pm 0.41^{\mathrm{b}}$ & -0.11 & $0.28 \pm 0.04^{\mathrm{ab}}$ \\
A2 & $2.75 \pm 0.05^{\mathrm{c}}$ & -0.68 & $0.69 \pm 0.04^{\mathrm{c}}$ & -0.72 & $2.76 \pm 0.39^{\mathrm{c}}$ & -0.38 & $0.25 \pm 0.02^{\mathrm{b}}$ \\
A3 & $1.67 \pm 0.03^{\mathrm{d}}$ & -0.77 & $0.37 \pm 0.02^{\mathrm{d}}$ & -0.87 & $1.16 \pm 0.25^{\mathrm{d}}$ & -0.72 & $0.22 \pm 0.03^{\mathrm{bc}}$ \\
\hline
\end{tabular}

${ }^{\mathrm{a}, \mathrm{b}, \mathrm{c}, \mathrm{d}}$ Mean within a column with no common superscripts are significantly different $(P<0.05)$

\subsection{Effect of Decomposing Leaf Litter of E. grandis on Pigment Content and Photosynthetic Characteristics of L. perenne Seedlings}

The photosynthetic pigment contents were significantly negative affected by decomposing leaf litter of $E$. grandis $(\mathrm{P}<0.05)$, and the degree of the effects increase with the increment of leaf litter amount (Table 2). The content of $\mathrm{Chl} \mathrm{a}, \mathrm{Chl} \mathrm{b}$ and $\mathrm{Chl}(\mathrm{a}+\mathrm{b})$ in A1 dropped by $6.89 \%, 26.3 \%$ and $10.8 \%$, respectively, compared to $\mathrm{CK}$, and the magnitude of the declines were $57.1 \%, 59.6 \%$ and $57.1 \%$ in the A3 treatment. The changes in the content of Car were same as the chlorophyll in the four treatments. The Car of A3 group was lower than that of CK group by $47.9 \%$ $(\mathrm{P}<0.05)$, and response index of allelopathy was -0.54 in $\mathrm{A} 3$.

Table 2. Effect of decomposing leaf litter of E. grandis on pigment content of $L$. perenne seedlings

\begin{tabular}{lllllllll}
\hline Treatment & $\begin{array}{l}\text { Chl a } \\
(\mathrm{mg} / \mathrm{g} \mathrm{FM})\end{array}$ & $R I$ & $\begin{array}{l}\text { Chl b } \\
(\mathrm{mg} / \mathrm{g} \mathrm{FM})\end{array}$ & $R I$ & $\begin{array}{l}\text { Chl (a+b) } \\
(\mathrm{mg} / \mathrm{g} \mathrm{FM})\end{array}$ & $R I$ & $\begin{array}{l}\text { Car } \\
(\mathrm{mg} / \mathrm{g} \mathrm{FM})\end{array}$ & $R I$ \\
\hline CK & $2.03 \pm 0.18^{\mathrm{a}}$ & $\backslash$ & $0.57 \pm 0.14^{\mathrm{a}}$ & $\backslash$ & $2.59 \pm 0.17^{\mathrm{a}}$ & $\backslash$ & $0.48 \pm 0.03^{\mathrm{a}}$ & $\backslash$ \\
$\mathrm{A} 1$ & $1.89 \pm 0.11^{\mathrm{b}}$ & -0.18 & $0.42 \pm 0.09^{\mathrm{b}}$ & -0.18 & $2.31 \pm 0.13^{\mathrm{b}}$ & -0.18 & $0.41 \pm 0.04^{\mathrm{b}}$ & -0.17 \\
$\mathrm{~A} 2$ & $1.25 \pm 0.05^{\mathrm{c}}$ & -0.37 & $0.33 \pm 0.04^{\mathrm{c}}$ & -0.39 & $1.57 \pm 0.05^{\mathrm{c}}$ & -0.38 & $0.34 \pm 0.02^{\mathrm{c}}$ & -0.33 \\
A3 & $0.87 \pm 0.03^{\mathrm{d}}$ & -0.58 & $0.23 \pm 0.02^{\mathrm{d}}$ & -0.54 & $1.11 \pm 0.03^{\mathrm{d}}$ & -0.58 & $0.25 \pm 0.02^{\mathrm{d}}$ & -0.54 \\
\hline
\end{tabular}

${ }_{\mathrm{a}, \mathrm{b}, \mathrm{c}, \mathrm{d}}$ Mean within a column with no common superscripts are significantly different $(P<0.05)$

$\mathrm{Chl} \mathrm{a}=$ chlorophyll $\mathrm{a}$; Chl b= chlorophyll b; Car = carotenoids. 
The photosynthetic characteristics including net photosynthetic rate, stomatal conductance and transpiration rate in leaf of $L$. perenne displayed decreasing trend with increasing of leaf litter of E. grandis in soil (Table 3 ), and the differences were significant among each treatment. Whereas the change of intercellular carbon dioxide concentration tended to rise, and marked by A3 $>\mathrm{A} 2>\mathrm{A} 1>\mathrm{CK}(P<0.05)$, the range of $R I$ was from 0.07 to 0.11 in this trait.

Table 3. Effects of decomposing leaf litter of $E$. grandis on photosynthetic rate and gas exchange parameters of $L$. perenne seedlings

\begin{tabular}{ccccccccc}
\hline Treatment & $\begin{array}{c}P n \\
\mu \mathrm{mol}\end{array}$ & $R I$ & $\begin{array}{c}G s \\
\mathrm{~mol} \\
\mathrm{HO}_{2} \mathrm{O}^{-2} \cdot \mathrm{m}^{-2} \cdot \mathrm{s}^{-1}\end{array}$ & $R I$ & $\begin{array}{c}\mathrm{Ci} \\
\mathrm{mmol} \\
\mathrm{CO}_{2} \cdot \mathrm{mol}^{-1}\end{array}$ & $R I$ & $\begin{array}{c}\text { Tr } \\
\text { mol } \\
\mathrm{H}_{2} \mathrm{O} \cdot \mathrm{m}^{-2} \cdot \mathrm{s}^{-1}\end{array}$ & $R I$ \\
\hline $\mathrm{ck}$ & $13.8 \pm 0.76^{\mathrm{a}}$ & $\backslash$ & $0.33 \pm 0.03^{\mathrm{a}}$ & $\backslash$ & $283.7 \pm 12.2^{\mathrm{c}}$ & $\backslash$ & $4.85 \pm 0.23^{\mathrm{a}}$ & $\backslash$ \\
$\mathrm{A} 1$ & $8.98 \pm 0.56^{\mathrm{b}}$ & -0.21 & $0.17 \pm 0.02^{\mathrm{b}}$ & -0.38 & $290.9 \pm 13.4^{\mathrm{b}}$ & 0.07 & $4.23 \pm 0.18^{\mathrm{a}}$ & -0.11 \\
$\mathrm{~A} 2$ & $7.06 \pm 0.45^{\mathrm{c}}$ & -0.32 & $0.15 \pm 0.01^{\mathrm{b}}$ & -0.49 & $295.3 \pm 11.2^{\mathrm{b}}$ & 0.19 & $3.15 \pm 0.18^{\mathrm{b}}$ & -0.24 \\
$\mathrm{~A} 3$ & $5.18 \pm 0.41^{\mathrm{d}}$ & -0.57 & $0.12 \pm 0.01^{\mathrm{c}}$ & -0.052 & $304.1 \pm 14.5^{\mathrm{a}}$ & 0.11 & $2.92 \pm 0.11^{\mathrm{c}}$ & -0.29 \\
\hline
\end{tabular}

${ }^{\mathrm{a}, \mathrm{b}, \mathrm{c}, \mathrm{d}}$ Mean within a column with no common superscripts are significantly different $(P<0.05)$.

\subsection{Correlation between the Growth Indices and Photosynthesis Parameters of L. perenne Leaves}

The correlation between the growth indices and photosynthesis parameters of $L$. perenne leaves were shown in the Table 4. The relation among shoot biomass, root biomass and leaf area were significantly positive $(P<0.05)$ or extremely significantly positive $(P<0.01)$. Also, there were significantly or extremely significantly positive correlations between photosynthetic pigment contents in leaf and shoot biomass, root biomass, leaf area, $P n, C i$ and $\operatorname{Tr}(P<0.05, P<0.01)$. The $C i$ was negatively related to all indices.

Table 4. The correlation between the growth indices and photosynthesis parameters of L. perenne leaves

\begin{tabular}{llllllllll}
\hline Items & $\begin{array}{l}\text { Shoot } \\
\text { biomass }\end{array}$ & $\begin{array}{l}\text { Root } \\
\text { biomass }\end{array}$ & $\begin{array}{l}\text { Leaf } \\
\text { area }\end{array}$ & $\begin{array}{l}\text { Chl } \\
(\mathrm{a}+\mathrm{b})\end{array}$ & Car & Pn & Ci & Gs & Tr \\
\hline $\begin{array}{l}\text { Shoot } \\
\text { biomass }\end{array}$ & 1 & & & & & & & \\
Root biomass & $0.986^{* *}$ & 1 & & & & & & & \\
Leaf area & 0.812 & $0.885^{*}$ & 1 & & & & & & \\
Chl (a+b) & $0.902^{*}$ & $0.956^{* *}$ & $0.972^{* *}$ & 1 & & & & & \\
Car & $0.861^{*}$ & $0.921^{*}$ & $0.986^{* *}$ & $0.998^{* *}$ & 1 & & & & \\
$P n$ & 0.853 & $0.899^{*}$ & $0.923^{*}$ & $0.971^{* *}$ & $0.972^{* *}$ & 1 & & & \\
$C i$ & -0.801 & $-0.861^{*}$ & -0.852 & $-0.902^{*}$ & $-0.908^{*}$ & $-0.981^{* *}$ & 1 & & \\
$G s$ & $0.991^{* *}$ & $0.982^{* *}$ & 0.801 & $0.898^{*}$ & 0.853 & 0.844 & -0.827 & 1 & \\
$T r$ & 0.823 & $0.888^{*}$ & $0.938^{*}$ & $0.918^{*}$ & $0.901^{*}$ & 0.813 & -0.699 & 0.805 & 1 \\
\hline
\end{tabular}

* mean that the correlation is significant $(P<0.05)$, ** mean that the correlation is highly significant $(P<0.01)$.

\subsection{The Response of Photosynthetic Rate of L. perenne Leaf on the $\mathrm{CO}_{2}$ and Light in the Different Treatments}

Overall, the $P n$ went up with the increase in $\mathrm{CO}_{2}$ concentration in the different treatments. Specifically, the $P n$ picked up quickly at the lower $\mathrm{CO}_{2}$ concentration $\left(0 \sim 400 \mu \mathrm{mol} \cdot \mathrm{mol}^{-1}\right)$, but then the increase trends in four groups of $P n$ were gradually at the higher $\mathrm{CO}_{2}$ concentration (Figure 1). 


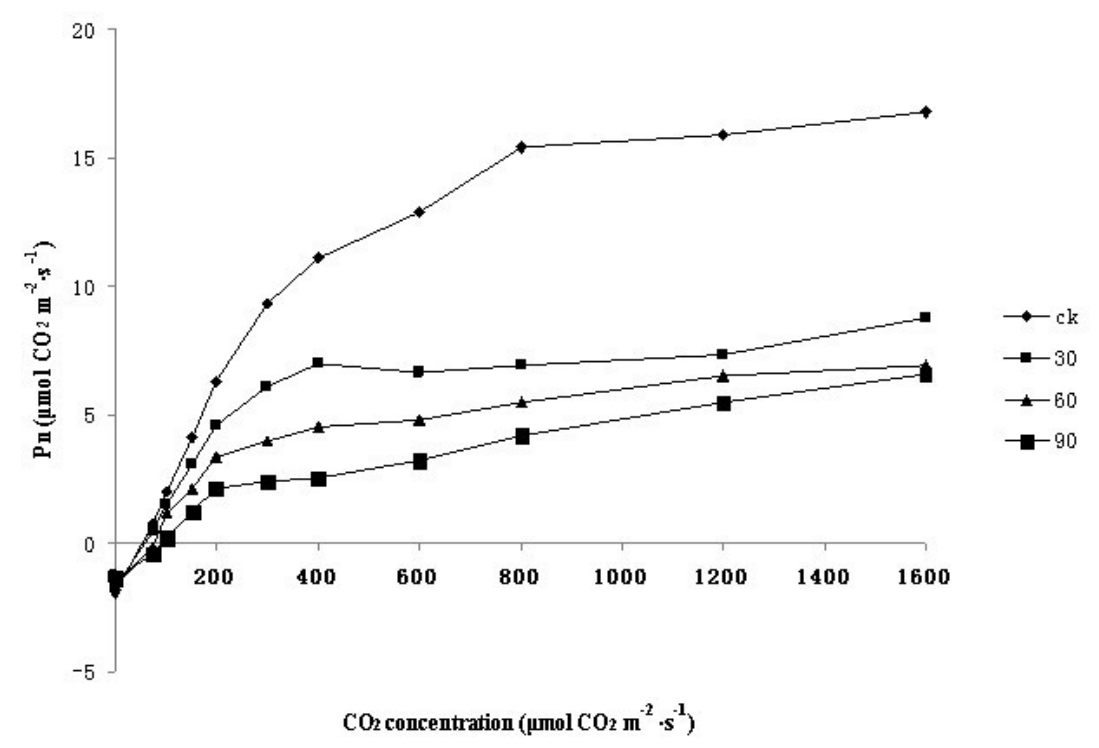

Figure 1. $\mathrm{CO}_{2}$ response curve of photosynthesis in L. perenne leaves in different leaf litter treatments

Parameters of photosynthetic rate of $L$. perenne leaf in response to $\mathrm{CO}_{2}$ concentration in each experiment group were shown in Table 5. There were significant falls in the RuBP carboxylation efficiency (CE), $\mathrm{P}_{\mathrm{n} \max }, \mathrm{CO}_{2}$ saturation point (CSP) and Photorespiration rate $\left(R_{p}\right)$ from $\mathrm{CK}$ to $\mathrm{A} 3$, whereas the $\mathrm{CO}_{2}$ compensation point (CCP) went up significantly with the increase of leaf litter of $E$. grandis $(P<0.05)$.

Table 5. Parameters of photosynthetic rate of $L$. perenne leaves in response to light intensity in different leaf litter treatments

\begin{tabular}{cccccc}
\hline Treatment & $\begin{array}{c}\text { AQY } \\
\left(\mu \mathrm{mol} \mathrm{CO}{ }_{2}\right. \\
\left.\mathrm{m}^{-2} \cdot \mathrm{s}^{-1}\right)\end{array}$ & $\begin{array}{c}\text { Pn max } \\
\left(\mu \mathrm{mol} \mathrm{CO}{ }_{2}\right. \\
\left.\mathrm{m}^{-2} \cdot \mathrm{s}^{-1}\right)\end{array}$ & $\begin{array}{c}\text { LSP } \\
(\mu \mathrm{mol} \text { photons } \\
\left.\mathrm{m}^{-2} \cdot \mathrm{s}^{-1}\right)\end{array}$ & $\begin{array}{c}\text { LCP } \\
(\mu \mathrm{mol} \mathrm{photons} \\
\left.\mathrm{m}^{-2} \cdot \mathrm{s}^{-1}\right)\end{array}$ & $\begin{array}{c}R d \\
\left(\mu \mathrm{mol} \mathrm{CO} \mathrm{CO}_{2}\right. \\
\left.\mathrm{m}^{-2} \cdot \mathrm{s}^{-1}\right)\end{array}$ \\
\hline $\mathrm{ck}$ & $0.039 \pm 0.009^{\mathrm{a}}$ & $17.6 \pm 3.45^{\mathrm{a}}$ & $528 \pm 76.2^{\mathrm{a}}$ & $16.7 \pm 4.12^{\mathrm{a}}$ & $1.21 \pm 0.19^{\mathrm{a}}$ \\
$\mathrm{A} 1$ & $0.031 \pm 0.010^{\mathrm{b}}$ & $7.59 \pm 2.13^{\mathrm{b}}$ & $375 \pm 57.3^{\mathrm{b}}$ & $10.1 \pm 3.78^{\mathrm{b}}$ & $0.72 \pm 0.17^{\mathrm{b}}$ \\
$\mathrm{A} 2$ & $0.026 \pm 0.009^{\mathrm{c}}$ & $3.43 \pm 1.08^{\mathrm{c}}$ & $217 \pm 32.9^{\mathrm{c}}$ & $3.71 \pm 0.98^{\mathrm{c}}$ & $0.36 \pm 0.09^{\mathrm{c}}$ \\
$\mathrm{A} 3$ & $0.023 \pm 0.008^{\mathrm{d}}$ & $3.19 \pm 1.12^{\mathrm{c}}$ & $207 \pm 33.6^{\mathrm{c}}$ & $3.02 \pm 0.87^{\mathrm{d}}$ & $0.31 \pm 0.07^{\mathrm{c}}$ \\
\hline
\end{tabular}

${ }_{\mathrm{a}, \mathrm{b}, \mathrm{c}, \mathrm{d}}$ Mean within a column with no common superscripts are significantly different $(P<0.05)$

$\mathrm{AQY}=$ apparent quantum yield, $\mathrm{LSP}=$ light saturation point and $\mathrm{LCP}=$ light compensation point.

The $P_{n}$ went up as the increase of the photosynthetically available radiation (PAR) in the four groups of treatments (Figure 2). Especially, the $P n$ of $L$. perenne leaf rose rapidly at lower light intensity $\left(0 \sim 200 \mu \mathrm{mol} \mathrm{mol} \mathrm{m}^{-2} \mathrm{~s}^{-1}\right)$. However, changing trends were stable when the PAR was above $800 \mu \mathrm{mol} \mathrm{mol}^{-2} \mathrm{~s}^{-1}$ in three treat groups. 


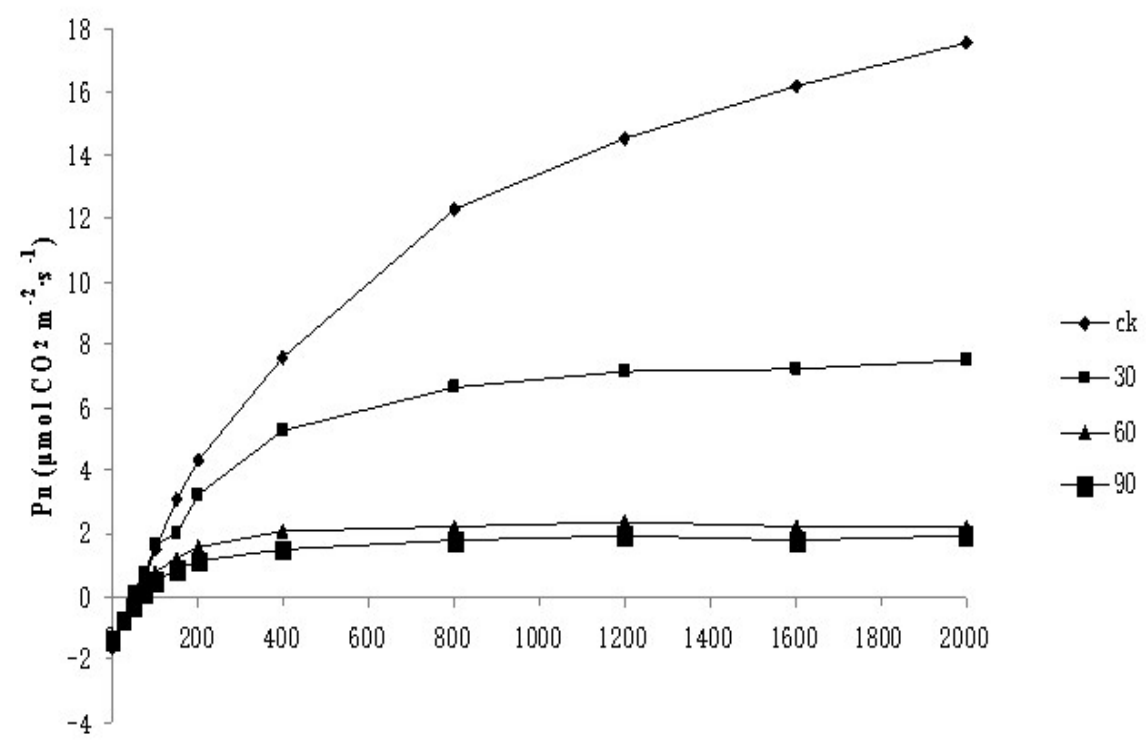

PAR (umolphotons $\left.\mathrm{m}^{-2} \cdot \mathrm{s}^{-1}\right)$

Figure 2. Light response curve of photosynthesis in L. perenne leaves in different leaf litter treatments

The values of apparent quantum yield (AQY), $P_{n \max }$, light saturation point (LSP), light compensation point (LCP) and $R_{d}$ were shown in Table 6 . The allelochemicals from decomposing leaf litter had significant effects on these five indices $(P<0.05)$. For AQY, $P_{n \max }, \mathrm{LSP}$ and $R_{d}$, there was no obvious difference between A3 and A4, but these two groups were significantly lower than $\mathrm{A} 2$ and $\mathrm{CK}(P<0.05)$, meanwhile, the A2 was dramatically lower than CK $(P<0.05)$. For LCP, the significant difference was observed among four groups, marked by $\mathrm{CK}>\mathrm{A} 1>$ $\mathrm{A} 2>\mathrm{A} 3(P<0.05)$.

Table 6. Parameters of photosynthetic rate of $L$. perenne leaves in response to $\mathrm{CO}_{2}$ concentrate in different leaf litter treatments

\begin{tabular}{cccccc}
\hline Treatment & $\begin{array}{c}\mathrm{CE} \\
(\mu \mathrm{mol}\end{array}$ & $\begin{array}{c}\mathrm{P}_{\mathrm{n} \max } \\
(\mu \mathrm{mol}\end{array}$ & $\begin{array}{c}\mathrm{CSP} \\
(\mu \mathrm{mol}\end{array}$ & $\begin{array}{c}\mathrm{CCP} \\
(\mu \mathrm{mol}\end{array}$ & $\begin{array}{c}\mathrm{R}_{\mathrm{p}} \\
((\mu \mathrm{mol}\end{array}$ \\
& $\left.\mathrm{CO}_{2} \mathrm{~m}^{-2} \cdot \mathrm{s}^{-1}\right)$ & $\left.\mathrm{CO}_{2} \mathrm{~m}^{-2} \cdot \mathrm{s}^{-1}\right)$ & $\left.\mathrm{CO}_{2} \mathrm{~m}^{-2} \cdot \mathrm{s}^{-1}\right)$ & $\left.\mathrm{CO}_{2} \mathrm{~m}^{-2} \cdot \mathrm{s}^{-1}\right)$ & $\left.\mathrm{CO}_{2} \mathrm{~m}^{-2} \cdot \mathrm{s}^{-1}\right)$ \\
\hline $\mathrm{ck}$ & $0.068 \pm 0.013^{\mathrm{a}}$ & $22.6 \pm 3.98^{\mathrm{a}}$ & $628 \pm 101^{\mathrm{a}}$ & $45.2 \pm 5.43^{\mathrm{d}}$ & $2.83 \pm 0.45^{\mathrm{a}}$ \\
$\mathrm{A} 1$ & $0.059 \pm 0.011^{\mathrm{b}}$ & $12.7 \pm 2.78^{\mathrm{b}}$ & $475 \pm 107^{\mathrm{b}}$ & $52.3 \pm 5.12^{\mathrm{c}}$ & $2.22 \pm 0.51^{\mathrm{b}}$ \\
$\mathrm{A} 2$ & $0.042 \pm 0.012^{\mathrm{c}}$ & $7.15 \pm 2.81^{\mathrm{c}}$ & $412 \pm 99.2^{\mathrm{c}}$ & $64.1 \pm 5.71^{\mathrm{b}}$ & $1.79 \pm 0.44^{\mathrm{c}}$ \\
$\mathrm{A} 3$ & $0.035 \pm 0.008^{\mathrm{d}}$ & $6.34 \pm 2.45^{\mathrm{c}}$ & $368 \pm 89.1^{\mathrm{d}}$ & $81.9 \pm 7.62^{\mathrm{a}}$ & $1.32 \pm 0.31^{\mathrm{d}}$ \\
\hline
\end{tabular}

a,b,c, Means within a column with no common superscripts are significantly different $(P<0.05)$.

$\mathrm{CE}=\mathrm{RuBP}$ carboxylation efficiency, $\mathrm{CSP}=\mathrm{CO}_{2}$ saturation point and $\mathrm{CCP}=\mathrm{CO}_{2}$ compensation point.

\subsection{Effect of Distilled Leaf Litter of E. grandis on Growth Indices and $P_{n}$ of L. perenne Seedlings}

The effect of distilled leaf litter of $E$. grandis on growth indices of $L$. perenne seedlings were also tested in this study. From the Table 7, there were no significant differences observed in the leaf area, shoot biomass, root biomass and photosynthetic among the different experimental groups $(P>0.05)$. Similarly, no significant differences were observed in the index of photosynthetic rate between the control group and each treatment group $(P>0.05)$. 
Table 7. Effect of distilled leaf litter of E. grandis on growth indices and $P_{n}$ of L. perenne seedlings

\begin{tabular}{lllll}
\hline Treatment & $\begin{array}{l}\text { Leaf area } \\
\left(\mathrm{cm}^{2} / 10 \text { plant }\right)\end{array}$ & $\begin{array}{l}\text { Shoot biomass } \\
(\mathrm{g} / 10 \text { plants })\end{array}$ & $\begin{array}{l}\text { Root biomass } \\
(\mathrm{g} / 10 \text { plants })\end{array}$ & $\begin{array}{l}\text { Photosynthetic } \\
\left(\mu \mathrm{mol} \mathrm{CO}_{2} \mathrm{~m}^{-2} \cdot \mathrm{s}^{-1}\right)\end{array}$ \\
\hline ck & $5.22 \pm 0.56^{\mathrm{a}}$ & $6.22 \pm 0.56^{\mathrm{a}}$ & $1.32 \pm 0.09^{\mathrm{a}}$ & $16.25 \pm 1.28^{\mathrm{a}}$ \\
$\mathrm{A} 1$ & $5.14 \pm 0.41^{\mathrm{a}}$ & $6.14 \pm 0.41^{\mathrm{a}}$ & $1.31 \pm 0.18^{\mathrm{a}}$ & $16.18 \pm 1.34^{\mathrm{a}}$ \\
$\mathrm{A} 2$ & $5.19 \pm 0.54^{\mathrm{a}}$ & $5.99 \pm 0.54^{\mathrm{a}}$ & $1.28 \pm .008^{\mathrm{a}}$ & $16.22 \pm 1.22^{\mathrm{a}}$ \\
$\mathrm{A} 3$ & $5.33 \pm 0.32^{\mathrm{a}}$ & $6.33 \pm 0.32^{\mathrm{a}}$ & $1.33 \pm 0.11^{\mathrm{a}}$ & $16.42 \pm 1.37^{\mathrm{a}}$ \\
\hline
\end{tabular}

a,b,c,d Means within a column with no common superscripts are significantly different $(P<0.05)$

\section{Discussion}

Although grass production is a complex biological process, its essence is the accumulation of dry matter via carbon assimilation driven by light energy (Knox et al., 2010). Commonly, about $90 \%$ to $95 \%$ of the biological yield of grass comes from photosynthetic product. Therefore, photosynthesis is a vital factor to determine the production of crop (Wang et al., 2010). Photosynthesis is a complex physiological process, which is influenced by the self-factors such as chlorophyll content, leaf thickness and mature grade of leaf, as well as correlated nearly with external factors such as light intensity, temperature, relative humidity, soil moisture balance (Cheng et al., 2009). Photosynthesis can be influenced by several factors, but all groups were treated by the same method and planted at one environment condition in our trail, therefore we considered the decomposition of leaf litter was the only factor to affect the photosynthesis of $L$. perenne seedling in different treat groups of our study.

It has been proven that leaf litter can release chemicals, which influence directly or indirectly on the growth and distribution of plants and microbes during the process of its decomposing. In this research, the ratio of root and shoot of the receptor were decreased with the increase of leaf litter of $E$. grandis, and root/shoot in A3 and A2 was significant lower than that of CK $(P<0.05)$, meanwhile, which in A3 was remarkable lower than A1 $(P<0.05)$. It showed that the effect of allelopathy on root may more sensitive, and was consistent with the report that allelochemicals firstly acted on membranes of plants' root cells, and influenced the functions of cell membranes through affecting the membrane potential, activity and permeability, ultimately influenced the photosynthesis by a series of biological mechanisms (Lang et al., 2009).

Photosynthetic pigments, especially the chlorophyll is the foundation of organic nutrient in grass, and play important roles in accepting and converting light energy into biochemical energy (Kana et al., 2008). Chl a is a major part of complex in the center of reaction, and serves the function in energy conversion, while Chl b is an important component of light-harvesting complex protein, and mainly applies in harvesting and transferring of light (Krause et al., 1991). Theoretically, the decrease of $\mathrm{Chl}$ a and $\mathrm{Chl} \mathrm{b}$ will undoubtedly reduce the photosynthesis. Several studies have proven that chlorophyll can be affected by allelochemicals in different kinds of plants (Einhellig et al., 1979; Yang et al., 2004; Yang et al., 2002). In our current study, we demonstrated that the accumulation of photosynthetic pigments in leaves of $L$. perenne was inhibited by the leaf litter of E. grandis. This could ultimately lead to the decrease in photosynthesis of L. perenne.

In the process of photosynthesis, the spread of $\mathrm{CO}_{2}$ from air to photosynthetic part in the chloroplast was affect by many factors, including $\mathrm{CO}_{2}$ conductance, stomatal conductance, mosephyll conductance, intercellular $\mathrm{CO}_{2}$ concentration and so on (Hanba et al., 2003). Stomata, as the most important gas transport channels in plant leaves, directly controls the access of $\mathrm{CO}_{2}$ and leaves transpiration. Wong et al. (1994) found that there is a feedback between $G_{s}$ and $P_{n}$ that the $G_{s}$ increase in favor of photosynthesis in mesophyll cells, whereas the $G_{s}$ decrease under unfavorable circumstances. Pattersion (1981) showed that cinnamic acid, benzoic acid, salicylic acid and several of allelochemicals can not only limit the increase of dry matter, leaf area and plant weight in Glycine max, but also inhibited the $P_{n}$ and $G_{s}$ of leaves. Mersie and Singh (1993) reported that the allelochemicals such as ferulic acid and vanillic acid can cause a significant decline in $P_{n}$ of Calathea leopardina leaves with decrease of $G_{s}$. In our research, the decomposition of $E$. grandis leaf litter negatively affected the $T_{r}$ and $G_{s}$ of $L$. perenne seedlings, and ultimately resulted in decrease of $P_{n}$ in A1, A2 and A 3 treatments. This illustrated that allelochemicals released from decomposition of leaf litter could destroy photosynthesis, impeded the growth of L. perenne seedlings finally. 
In a certain environmental condition, the $P_{n \max }$ represents the maximum photosynthetic capacity of leaf (Lu et al., 2001). Apparent quantum yield (AQY) reflects the utilization of the light energy, especially in weak light (Kisch, 2010). $\mathrm{CO}_{2}$ saturation point (CSP) indicates that when the concentration of $\mathrm{CO}_{2}$ is low in the air, the photosynthetic rate goes up with the increasing of concentration of $\mathrm{CO}_{2}$, and the rise of photosynthetic rate will stop at a certain concentration of $\mathrm{CO}_{2}$ (Cao et al., 2011). In this study, the $P_{n \max }$, AQY and LSP significantly decreased with the increase of the amount of leaf litter, which indicated that allelochemicals may reduce the response of $L$. perenne seedlings to the changing of concentrate of $\mathrm{CO}_{2}$ and light.

There was no significant effect on the leaf area, shoot biomass, root biomass and photosynthetic when the distilled leaf litters of E. grandis were added into the soil in each treatment. This demonstrated that the soil physical properties, especially soil aeration and water permeability were not been obviously changed after the addition of leaf litter into the soil and in the process of leaf litter decomposition, because allelochemicals have been removed from the leaf litter by distilling, and further showed that the differences in growth of $L$. perenne seedlings were mainly caused by allelochemicals which were released from the decomposition of original leaf litter of $E$. Grandis.

\section{Conclusion}

In conclusion, allelochemicals released from decomposing $E$. Grandis leaf litter can inhibit the opening of stomata on leaves, and decrease the content of synthesis of photosynthetic pigments and the response to $\mathrm{CO} 2$ concentration and light intensity in $L$. perenne. These can reduce the photosynthetic capacity of leaves, and eventually inhibiting the growth of height and leaf area and the accumulation of biomass of L. perenne. Our results can provide basis research and reasonable suggestion on allelopathy, and provide a management strategy for $E$. grandis plantation and its compound system with grass as well. However, the main limitation of our study was the small number of samples, and further large-scale research should be conducted to check the effects of this allelopathy of $E$. Grandis on the growth of L. perenne.

\section{Acknowledgements}

This study was financially supported by the National Key Technology R\&D Programs of China during $11^{\text {th }}$ and $12^{\text {th }}$ Five-Year Plan Period (No. 2008BADC2B01 and No. 2011BAC09B05), and Major Project Fund of Sichuan Provincial Education Department (No. 09ZA079).

\section{References}

Campoe, O. C., Stape, J. L., Nouvellon, Y., Laclau, J. P., Bauerle, W. L., Binkley, D., \& Le Maire, G. (2013). Stem production, light absorption and light use efficiency between dominant and non-dominant trees of Eucalyptus grandis across a productivity gradient in Brazil. Forest Ecology and Management, 288(15), 14-20. http://dx.doi.org/10.1016/j.foreco.2012.07.035

Cao, Z., Zhou, G., Wen, G., Jiang, P., Zhuang, S., Qin, H., \& Wong, M. (2011). Bamboo in Subtropical China: Efficiency of Solar Conversion into Biomass and $\mathrm{CO}_{2}$ Sequestration. Botanical Review, 77(3), 190-196. http://dx.doi.org/10.1007/s12229-011-9075-y

Cheng, Y. C., \& Fleming, G. R. (2009). Dynamics of light harvesting in photosynthesis. Annual Review of Physical Chemistry, 60, 241-262. http://dx.doi.org/10.1146/annurev.physchem.040808.090259

Einhellig, F. A., \& Rasmussen, J. A. (1979). Effects of three phenolic acids on chlorophyll content and growth of soybean and grain sorghum seedlings. Journal of Chemical Ecology, 5(5), 815-824. http://dx.doi.org/10.1007/BF00986566

Goya, J. F., Frangia, J. L., Péreza, C., \& Dalla Teab, F. (2008). Decomposition and nutrient release from leaf litter in Eucalyptus grandis plantations on three different soils in Entre Ríos, Argentina. Bosque, 29(3), 217-226.

Hanba, Y. T., Kogami, H., \& Terashima, I. (2003). The effect of internal CO2 conductance on leaf carbon isotope ratio. Isotopes in Environmental and Health Studies, 39(1), 5-13.

Jairus, T., Mpumba, R., Chinoya, S., \& Tedersoo, L. (2011). Invasion potential and host shifts of Australian and African ectomycorrhizal fungi in mixed eucalypt plantations. New Phytologist, 192(1), 179-187. http://dx.doi.org/10.1111/j.1469-8137.2011.03775.x

Kana, T. M., Geider, R. J., \& Critchley, C. (2008). Regulation of photosynthetic pigments in micro - algae by multiple environmental factors: a dynamic balance hypothesis. New Phytologist, 137(4), 629-638. http://dx.doi.org/10.1046/j.1469-8137.1997.00857.x

Kisch, H. (2010). On the problem of comparing rates or apparent quantum yields in heterogeneous photocatalysis. Angewandte Chemie, 122(50), 9782-9783. http://dx.doi.org/10.1002/ange.201002653 
Knox, J., Morris, J., \& Hess, T. (2010). Identifying future risks to UK agricultural crop production: Putting climate change in context. Outlook on Agriculture, 39(4), 249-256. http://dx.doi.org/10.5367/oa.2010.0016

Krause, G., \& Weis, E. (1991). Chlorophyll fluorescence and photosynthesis: the basics. Annual Review of Plant Biology, 42(1), 313-349. http://dx.doi.org/10.1146/annurev.arplant.42.1.313

Lang, S. I., Cornelissen, J. H. C., Klahn, T., Van Logtestijn, R. S. P., Broekman, R., Schweikert, W., \& Aerts, R. (2009). An experimental comparison of chemical traits and litter decomposition rates in a diverse range of subarctic bryophyte, lichen and vascular plant species. Journal of Ecology, 97(5), 886-900. http://dx.doi.org/10.1111/j.1365-2745.2009.01538.x

Lee, J. M., Roche, J. R., Donaghy, D. J., Thrush, A., \& Sathish, P. (2010). Validation of reference genes for quantitative RT-PCR studies of gene expression in perennial ryegrass (Lolium perenne L.). BMC Molecular Biology, 11(1), 8-13. http://dx.doi.org/10.1186/1471-2199-11-8

Li, H. S., Sun, Q., \& Zhao, S. J. (2000). Plant Physiology and Biochemistry Principles and Experimental Techniques. Beijing: Higher Education Press, 134-137 (in Chinese).

Lu, P. L., Luo, Y., \& Liu, J. D. (2001). Characteristic parameters of light respons curve of photosyenthsis of winter wheat in north China. Quarterly Journal of Applied Meteorlolgy, 11, 236-241.

Wang, H. M., Li, X. W., \& Li, S. J. (2003). Study of Forest-Grass Compound Management Mode Sichuan Forestry Exploration and Design, 1, 5-9 (In Chinese).

Wang, R., Liu, G. S., Bi, Q. W., Li, G., Zheng, C. H., \& Liu, H. (2010). Effects of plastic film mulching in whole growth period on the photosynthesis function, yield, and quality of flue-cured tobacco at different elevations in ENshi of Hubei Province. Chinese Journal of Ecology, 29, 43-49 (In Chinese).

Yang, C. M., Chang, F., Lin, S. J., \& Chou, C. H. (2004). Effects of three allelopathic phenolics on chlorophyll accumulation of rice (Oryza sativa) seedlings: II. Stimulation of consumption-orientation. Botanical Bulletin of Academia Sinica, 45, 119-125.

Yang, C. M., Lee, C. N., \& Chou, C. H. (2002). Effects of three allelopathic phenolics on chlorophyll accumulation of rice (Oryza sativa) seedlings: I. Inhibition of supply-orientation. Botanical Bulletin of Academia Sinica, 43, 299-304.

Yu, Z., Jian, Z., Wan, Q. Y., Fu, Z. W., Mao, S. F., \& Xiao, H. C. (2009). Allelopathic effects of Eucalyptus grandis on Medicago sativa growing in different soil water conditions. Acta Prataculturae Sinica, 18(4), 81-86.

Zhang, J., \& Yang, W. Q. (2008). Ecosystem reserach on Eucalypt (Eucalypt grandis) shortterm rotation plantation. Chengdu: Sichuan Science and Technology Press (In Chinese). 